\title{
Why is There No NATO in Asia? Collective Identity, Regionalism, and the Origins of Multilateralism
}

\author{
Christopher Hemmer and Peter J. Katzenstein
}

Regional groupings and regional effects are of growing importance in world politics. Although often described in geographical terms, regions are political creations and not fixed by geography. Even regions that seem most natural and inalterable are products of political construction and subject to reconstruction attempts. Looking at specific instances in which such constructions have occurred can tell us a great deal about the shape and the shaping of international politics.

In the aftermath of World War II, the United States attempted to create and organize both a North Atlantic and a Southeast Asian region. The institutional forms of these regional groupings, however, differed dramatically. With its North Atlantic partners, the United States preferred to operate on a multilateral basis. With its Southeast Asian partners, in contrast, the United States preferred to operate bilaterally. Why? Perceptions of collective identity, we argue, played an underappreciated role in this decision. Shaped by racial, historical, political, and cultural factors, U.S. policymakers saw their potential European allies as relatively equal members of a shared community. America's potential Asian allies, in contrast, were seen as part of an alien and, in important ways, inferior community. At the beginning of the Cold War, this difference in mutual identification, in combination with material factors and considerations of efficiency, was of critical importance in defining the interests and shaping the choices of U.S. decision makers in Europe and Asia. Different forms of cooperation make greater or lesser demands on shared identities. Multilateralism is a particularly demanding form of international coop-

For criticisms and suggestions of earlier drafts of this paper, we would like to thank Tim Borstelmann, Steve Burgess, Allen Carlson, Jeffrey Checkel, Matthew Evangelista, Martha Finnemore, Judith Gentleman, Mary Hampton, Robert Keohane, Jonathan Kirshner, Masaru Kohno, Stephen Krasner, David Lai, Walter LaFeber, David Laitin, Kier Lieber, Rose McDermott, Matthew Rhodes, Thomas Risse, Jae-Jung Suh, and Chris Way. We also are grateful to the editors and reviewers of $I O$ whose careful readings have greatly improved this paper. The views expressed here are those of the authors alone and do not necessarily reflect the views of the Air War College or any other U.S. government department or agency. 
eration. It requires a strong sense of collective identity in addition to shared interests.

This case is of more than passing historical interest. In recent years, realist and liberal theorists of international relations have debated, more than once, the relative importance and efficacy of material capabilities versus institutions in world politics. Realists have argued that international anarchy and the security dilemma it creates make international institutions epiphenomenal or, at best, marginal to world politics. Liberals have claimed instead that institutions have noticeable effects that can ameliorate the security dilemma. After the end of the Cold War and the collapse of the Soviet Union, neorealist theory, for example, expected the North Atlantic Treaty Organization (NATO) to disintegrate quickly. Neoliberalism did not. Instead, neoliberals argued that NATO helped create conditions that were conducive to peace in Europe after 1945 and that, therefore, NATO was likely to prosper and endure. 'More than a decade has passed since the end of the Cold War and, far from disappearing, NATO is expanding.

The empirical research program of neoliberal institutionalism remains, however, largely restricted to a small pool of successful Western institutions such as NATO, the General Agreement on Tariffs and Trade/World Trade Organization (GATT/ WTO), or the European Union (EU). ${ }^{2}$ Even in these cases, neoliberal theory encounters uncomfortable difficulties. Why did the Warsaw Pact not persist as uncertainty increased in Eastern Europe's security environment in 1989-90? And why did NATO rather than the Organization for Security and Cooperation in Europe become Europe's preferred security regime in the 1990s? An exclusive focus on unmeasured institutional efficiencies that are created by a stipulated lowering of transaction costs and a variety of institutional asset specificities risks slighting the causal importance of material capabilities and collective identities. "Institutional assets," writes Celeste A. Wallander, "affect the costs and effectiveness of alternative strategies, but they do not determine purpose." 3

Neoliberal institutionalism's central claim - that institutions develop when states foresee self-interested benefits from cooperation under conditions that are propitious for overcoming obstacles to cooperation-remains in need of further testing and refinement. "A single, deductive model is a bridge too far," conclude Barbara Koremenos, Charles Lipson, and Duncan Snidal, further stating that "Bedrock preferences are constant - a hallmark assumption and limitation of the rational approach." ${ }^{4}$ Security arrangements in Asia remain a puzzle. Multilateral institutions failed despite the presence of self-interested benefits from cooperation. Even though, as in Europe, multilateral security arrangements would have provided information, reduced transaction costs, made commitments more credible, and established focal points for coordinating policies, after 1945 the U.S. government

1. See Duffield 1998; Haftendorn, Keohane, and Wallander 1999; and Wallander 1999 and 2000.

2. Kohno 1996.

3. Wallander 2000,712 .

4. Koremenos, Lipson, and Snidal 2001, 1065, 1074. 
opted for a hub-and-spokes system of bilateral alliances in Asia with the United States at the center. "If NATO was so successful in Europe," asks Masaru Kohno, "why was it not copied in East Asia in the aftermath of World War II?"5 Neoliberal theory, by itself, offers no compelling answer to this question.

Neither does a realist analysis that focuses exclusively on capabilities and interests. Realist scholars are right to insist that the main U.S. interests were served well by forming a set of bilateral alliances in Asia. ${ }^{6}$ But they remain silent on the issue of why those interests favored multilateral arrangements in Europe and bilateral ones in Asia. Material capabilities alone offer little help in answering the question of why there was no NATO in Asia.

Strict formulations of both liberalism and realism are less convincing than eclectic variants that also incorporate important insights from constructivist theory. ${ }^{7}$ Eclectic explanations highlight the causal importance of social facts such as power status and threat perceptions, in addition to the material facts and efficiency considerations stressed by rationalist approaches. Eclectic explanations also undercut reifications such as the distinction between domestic and international levels of analysis. Theoretical eclecticism cuts against the paradigmatic organization of most contemporary scholarship on international relations. Thinking in terms of schools of thought, as James Fearon and Alex Wendt argue, at the very least can "encourage scholars to be method-driven rather than problem-driven in their research, which may result in important questions or answers being ignored if they are not amenable to the preferred paradigmatic fashion." ${ }^{8}$ To liberalism, constructivism adds consideration of the effects identities have on both formal and informal institutions. To neorealism, it adds consideration of the effects of ideational rather than material structures, specifically the effects of identity on actor interests. ${ }^{9}$

In the second section of this article, we briefly contrast the policies the United States pursued in Europe and Asia during the early Cold War. Although strikingly little comparative work has been done contrasting U.S. foreign policy in Asia and Europe, in the following section we briefly explore explanations that can be gleaned from the existing literature on why the United States preferred multilateral organizing principles in Europe and bilateral ones in Asia. Next, we put forward three eclectic explanations that combine the material and efficiency factors stressed in realist and liberal explanations with social factors stemming from the different levels of identification American policymakers felt with regard to their European and Asian allies. Finally, we explore some of the theoretical and empirical implications of this argument.

5. Kohno 1996, 7.

6. Ibid., 29-33.

7. See Wendt 1999; Ruggie 1998; and Katzenstein 1996b.

8. Fearon and Wendt $2001,1$.

9. See Adler and Barnett 1998; Neumann 1999; and Acharya 2000 and 2001. 


\section{Constructing Regions and Regional Institutions After 1945}

When the U.S. Senate first began to debate the issue of a formal U.S. commitment to Europe following World War II, Senator Henry Cabot Lodge, Jr. was puzzled as his colleagues began to discuss the relationship between the United States and its potential European allies as a regional one. "Certainly," he argued, "the United States and Western Europe" could not be part of the same region. "Certainly," they could, Senator Arthur Vandenberg responded, "because this is a North Atlantic region." This exchange initiated a short debate over how far the concept of a region could be stretched. Could a region be anything a state wanted it to be, or did 3,000 miles of ocean render absurd any talk of a common region $?^{10}$ This brief exchange underscores the fact that regions do not just exist as material objects in the world. Geography is not destiny. ${ }^{11}$ Instead, regions are social and cognitive constructs that can strike actors as more or less plausible.

The creation of NATO and the Southeast Asian Treaty Organization (SEATO) form a natural parallel that has sparked surprisingly little attention from students of international politics. ${ }^{12}$ Comparing the two offers the historian of international relations something like a natural experiment. In the early Cold War, the United States initiated a number of regional alliances to help organize some recently defined regions. The form of these regional alliances, however, varied significantly. The United States consistently treated the newly minted North Atlantic region differently than the newly minted Southeast Asian region. In Europe, it opted to promote a multilateral framework. The United States preferred to deal bilaterally with its Asian allies. Why? Because most of the secondary literature on the creation of these two alliances predates the current theoretical concern with the question of bilateralism versus multilateralism, it is not very illuminating on this issue.

Noting that more than two states make up the SEATO alliance, much secondary literature treats it as a multilateral alliance. SEATO, however, is not multilateral in the same sense as NATO.$^{13}$ First, the language of the treaty commitment is much weaker. Instead of the NATO commitment to collective defense as outlined in article $\mathrm{V}$, which states that an attack on one will be considered an attack on all, article IV of the SEATO treaty merely classifies such an attack as a threat to peace and safety. Furthermore, in SEATO the United States made it clear that it retained its prerogative to act bilaterally or unilaterally. This was formalized in the RuskThanat joint statement of 1962, in which the United States stressed that its commitment to Thailand "does not depend upon prior agreement of all the other parties to the treaty, since the obligation is individual as well as collective."14 Organizationally, the differences were just as apparent. In SEATO, there was no

10. U.S. Senate 1973, 14-19, 315-17.

11. Paasi 1986.

12. Duffield 2001, 69-72.

13. Ruggie 1997, 105.

14. Rusk and Thanat 1962, 498-99. 
unified command and no specifically allocated unified forces; and any actions taken under SEATO auspices were handled individually by the member states and not by the institution as a whole. ${ }^{15}$

U.S. policymakers contemplated the possibility of establishing an Asian NATO. Indeed, many of its prospective members favored the creation of a NATO-type institution. ${ }^{16}$ The United States, however, remained adamantly opposed to using NATO as the model and even discouraged the use of the phrase SEATO, fearing unwanted comparisons of the acronyms. As one member of the U.S. State Department wrote to John Foster Dulles:

In accordance with your suggestion ... we have attempted to get away from the designation "SEATO" so as to avoid fostering the idea than an organization is envisioned for SEA [Southeast Asia] and the Pacific similar to NATO. . . In spite of our efforts, the designation "SEATO" has stuck. . . I suggest that we accept that "SEATO" is here to stay and that we continue to make clear in our substantive discussions that so far as the US is concerned, the SEA Pact is not conceived as a parallel to NATO (emphasis in original). ${ }^{17}$

In the following section, we discuss existing arguments regarding the rise of multilateral or bilateral institutions to see what they can offer in the way of explanation for why the United States treated NATO and SEATO so differently.

\section{Universal and Indeterminate Explanations}

Even though most studies of the security arrangements the United States sought to create after World War II are regionally limited to Europe or Asia, many seek to explain the rise of multilateral or bilateral institutions with universal explanations. Once Europe and Asia are placed in a comparative perspective, however, the problem with these explanations becomes obvious. As universal explanations, they are unable to account for the regional differences in U.S. policy. A second set of explanations for America's preference for multilateral mechanisms in Europe and for bilateral mechanisms in Asia is underdetermined. The opportunities and constraints to which these accounts point as the driving force behind U.S. choices could have been satisfied by either bilateral or multilateral security arrangements. Therefore, by themselves, these explanations are insufficient.

\section{Universal Explanations}

More than any other scholar, John Ruggie has drawn our attention to the importance of multilateralism as a novel social institution in twentieth-century diplomacy. 
Ruggie focuses mostly on Europe in this context. ${ }^{18}$ He interprets the expansion of multilateral principles after World War II as the result of the U.S. "vision as to what constitutes a desirable world order." 19 According to this view, the United States has pushed multilateral principles abroad for a number of reasons. The principles are a convenient mask for U.S. hegemony. They duplicate U.S. domestic order. And they are consistent with the U.S. view of itself. ${ }^{20}$ While this explains why the United States may find multilateral principles attractive, it cannot explain why the United States pushed multilateralism much more in Europe than in Asia. Ruggie notes this difference, but does not attempt to account for it beyond noting that it "was not possible" to embrace multilateralism in Asia. ${ }^{21}$

Anne-Marie Burley offers a similarly universal explanation. ${ }^{22}$ Following Charles Maier, ${ }^{23}$ Burley argues that U.S. support for multilateralism was an attempt to apply the lessons the United States had learned from the Great Depression on an international scale. In essence, Burley argues, the United States attempted to implement a global New Deal following the war. However, this account suffers from the same limitations as Ruggie's. It cannot explain why the United States applied these global principles differently in different world regions. As David Lake notes, the United States projects its norms onto the global scene "in a highly selective fashion that itself needs to be explained." 24

Universal explanations derived from studies focusing on U.S. policy toward Asia during the Cold War are equally limited. One such explanation highlights the unwillingness of the United States to delegate authority. If the United States was going to bear the largest share of the burden for the military defense of Asia, why should it cede control or limit its freedom of action in a multilateral institution? ${ }^{25}$ In the words of one U.S. Department of Defense official, a "NATO pattern" in Asia would be "inimical to US interests in that it could... tend to reduce, without compensating military advantage, United States military freedom of action."26

This explanation also fails to account for the different policies the United States pursued in Europe and Asia. Why would the United States accept the loss of control entailed in the creation of multilateral institutions in Europe, but not in Asia? A realist could answer that the United States accepted this loss of control in Europe because the European states offered a "compensating military advantage." Such an explanation is undoubtedly partly correct. In their material power resources, European states offered more advantages to the United States than did Asian states. This, however, can only be part of the story. During the early Cold War, the United States

18. See Ruggie 1993 and 1994.

19. Ruggie 1994, 560. See also Legro 2000.

20. Ruggie 1994, 561-65.

21. Ruggie 1993, 4, 29.

22. Burley 1993.

23. Maier 1978.

24. Lake 1999, 218.

25. See Kim 1965, 68; and Webb 1962, 66 .

26. U.S. Department of State 1984, 767-68. 
was so far ahead of both the war-destroyed European states and the newly emerging states of Asia that any differences between these two regions was probably marginal compared to the huge gulf separating the United States from both. By itself, therefore, a general unwillingness to cede control to weaker allies in multilateral institutions cannot explain the regional difference in U.S. policy.

\section{Underdetermined Explanations}

Steven Weber's important work on the evolution of multilateralism in NATO argues that U.S. policymakers believed a multipolar world would be more stable than the bipolar world they saw come into existence following World War II. ${ }^{27}$ The only way for a multipolar world to come into being, however, would be for centers of power to emerge that were independent of the United States and the Soviet Union. The United States promoted multilateralism in Europe, according to Weber, to encourage the emergence of an independent center of power that could usher in a more peaceful period of multipolarity.

The logic of this argument, as Weber notes, would lead him to expect that the U.S. preference for multipolarity should also have led it to promote the development of independent centers of power in Asia as well as in Europe. ${ }^{28}$ In part, this expectation is confirmed-the United States did try to restore Japan's power. However, in building up an independent center of power in Asia, the United States chose to do so in terms of its bilateral relationship with Japan, rather than in terms of a regional multilateral institution. Thus by itself, the U.S. desire to see the emergence of independent centers of power has no direct relationship to the choice between bilateral or multilateral security arrangements.

A second underdetermined explanation points to the hostilities that existed between Japan and its neighbors after 1945. Fearful of Japan's re-emergence as an imperialist power, many Asian states were hesitant to join any Pacific alliance that had Japan as a member. ${ }^{29}$ For example, John Foster Dulles discovered that many prospective members of any Asian alliance "have memories of Japanese aggression that are so vivid that they are reluctant to create a Mutual Security Pact with Japan." 30

Yet fear of Japan does not offer a complete explanation for the U.S. decision to work bilaterally in Asia. Germany's pariah status following World War II was equal to if not greater than Japan's. Yet this pariah status did not prevent the United States from supporting and pursuing multilateral initiatives in Europe that would soon include Germany. ${ }^{31}$ There were many calls for the United States to rehabilitate Japan in the eyes of its neighbors so that it could become a member of a wider

27. See Weber 1991 and 1993.

28. Weber 1991, 16.

29. See Duffield 2001, 80-81; and Kohno 1996, 31-32.

30. Dulles 1952, 182.

31. Trachtenberg 1999. 
Pacific pact. Such a policy would have required a sharper break with the past than General MacArthur and the U.S. occupation of Japan were prepared to make, particularly with respect to the political status of Emperor Hirohito. ${ }^{32}$ In fact, the United States government never made the same efforts to integrate Japan into Asia through multilateral institutions as it did for Germany in Europe ${ }^{33}$ Had the United States pushed its Asian allies to accept Japan as hard as it pushed its European allies to integrate with Germany, similar institutions might have evolved in the two regions. $^{34}$

A third underdetermined argument centers on the Eisenhower administration's New Look policy. Central to this policy was reducing the defense budget by limiting reliance on costly ground troops and focusing on a less expensive nuclear deterrent. Some argue that the limited nature of the U.S. commitment to SEATO flowed from the fiscal conservatism and massive retaliation strategy of the Eisenhower administration, reinforced by the lessons of the Korean War. ${ }^{35}$ As Secretary of State Dulles put it during Senate hearings on the SEATO treaty:

We do not expect to duplicate in this area the pattern of the NATO [organization] and its significant standing forces. That would require a diversion of and commitment of strength which we do not think is either practical or desirable or necessary.

Instead, Dulles emphasized the "mobile striking power" of U.S. forces that need not and ought not be easily pinned down at many points around the circumference of the communist world. ${ }^{36}$

While this is a plausible explanation for why the United States wanted to limit any ground commitment to SEATO, it is less compelling as an explanation for the lack of multilateralism in SEATO. At the same time that the United States was creating SEATO, it was also trying to limit its ground commitments and increase reliance on nuclear deterrence in Europe. In NATO, however, the United States attempted to do this multilaterally through the sharing of nuclear weapons within the alliance. ${ }^{37}$ Thus limited ground commitments and a multilateral alliance structure could potentially have been as compatible in Asia as in Europe. The United States, however, did not try to make them compatible in Asia.

In sum, several universal or underdetermined explanations of the rise of multilateral and bilateral security institutions in Europe and Asia suffer from one of two weaknesses. They offer accounts that do not consider regional variations, or they identify constraints and opportunities for U.S. foreign policy that could have been satisfied by either bilateral or multilateral arrangements.

32. Bix 2000, 533-80.

33. Hampton $1998 / 99$.

34. U.S. Department of State 1984, 425-26.

35. See Marks 1993, 51-52; and Hess 1990, 280.

36. U.S. Senate 1954, 13-14, 17.

37. See Trachtenberg 1999, 147-215; and Weber 1991, 48-69. 


\section{Eclectic Explanations: Power, Threats, and Identity}

To account for the different policies pursued by the United States in building its alliances in Europe and Asia after World War II, realist analyses focus on the distribution of power among the United States and its putative allies and enemies, while liberal explanations focus on the relative efficiencies of different institutional forms. While both approaches offer some insight into NATO and SEATO origins, both rely, often implicitly, on non-rationalist arguments about identity to make their cases plausible. As Alastair Iain Johnston and David E. Spiro, among others, have argued in their eclectic rendering of a realist analysis, variables like power status and threats are social facts, whose significance, while anchored in material reality, cannot simply be read off material capabilities. ${ }^{38}$ Constructivist explanations that focus on identity alone are similarly incomplete. Divorced from the material and efficiency factors stressed by realists and liberals, constructivist arguments about the importance of identity risk being empirically too thin and analytically too malleable. Rather than seeking to establish the superiority of one approach over another, we develop eclectic explanations that offer compelling insights into a specific empirical puzzle.

\section{Great Power Status}

The relative weakness of the regional members of SEATO is a strong realist argument for why SEATO was not formed along NATO lines. The discrepancy between the power of the United States and the power of its Asian allies may have made the multilateral bargain an unattractive one for the United States. George Modelski, for example, argues that "in NATO the benefits and obligations are shared fairly equally. In SEATO the disparity between the great and small powers is greater. . . Most of SEATO's concrete operations represent one-way traffic to help area states and not a two-way cooperative enterprise." ${ }^{39}$ If it is restricted to material capabilities only, however, this explanation encounters some problems. A huge disparity between the United States and its regional allies existed not only in Asia but also in war-destroyed Europe. Moreover, Japan was not invited to join SEATO even though as a modern industrialized state it potentially could have contributed many resources to the fledgling alliance. Similarly, other regional states with strong militaries, like South Korea and Taiwan, were not invited to join the alliance. Material capabilities alone do not offer a compelling answer for why the United States did not pursue this course.

Great power status, however, did matter. U.S. officials believed that, despite current disparities in capabilities due to the ravages World War II had inflicted on Europe, their European allies would soon rebuild their strength, while their Asian 
allies would remain permanently weak. While U.S. policymakers may have acted condescendingly to their European partners, in comparison to their Asian allies, it was condescension tempered by the expectation of Europe's revival. Indeed, much of U.S. policy toward Europe was driven by the perception of the European states as great powers. According to Steve Weber, President Eisenhower, one of the strongest proponents of multilateralism in NATO, "held strong views about the traditional place of Britain, France and even Germany as great powers in world politics." Their position as "secondary actors ... was simply unnatural." ${ }^{\text {" }}$ Most Southeast Asian states, by way of contrast, were in the late 1940s only at the threshold of shedding their colonial status and gaining national sovereignty for the first time.

In Asia, the United States really had only one potential great power ally-Japan. ${ }^{41}$ However, an analysis focused solely on the material balance of power leaves important questions unanswered. ${ }^{42}$ In Asia, why did the United States not ally with China against the Soviet Union? The Chinese revolution and Mao's victory in 1949 was of critical importance. A threat is rooted not solely in differential material capabilities but also in the view of the difference between self and other that shapes interpretations of actor intentions and interests. Although conceivable in terms of material balance of power, for ideological reasons, communist China was not a plausible alliance partner for the United States after 1949. Eclectic theorizing enriches balance of power explanations.

\section{Efficient Responses to Threat}

A liberal explanation for why the United States failed to push multilateralism in Asia focuses on the different threats faced in Asia and Europe and the most institutionally efficient response to those threats. The military and civilian leadership in the United States was in general agreement that Southeast Asia was less important and less threatened than Europe. ${ }^{43}$ Furthermore, the threat in Asia, it could be argued, was one of national insurgencies rather than cross-border war. These differences suggest the appropriateness of different institutional countermeasures in the two regions.

In Europe, the military structure of NATO was designed to hold off a massive Soviet offensive. U.S. officials expected no large-scale offensive by either the Soviet Union or China in Asia. The primary problem for the United States in Asia was fighting communist insurgencies. Security arrangements designed to fend off a Soviet assault might not have been appropriate for dealing with national insurgencies. Indeed, they may have been counterproductive. The varied nature of the internal subversive threats faced by the different states may have made a "one-size-

40. Weber 1991, 41.

41. Duffield 2001, 77-80.

42. Reiter 1996, 41-54.

43. U.S. Department of State 1984, 3, 831. 
fits-all" multilateral defense arrangement like the one built in NATO inappropriate. $^{44}$ In one of the few references to SEATO in his memoirs, Eisenhower approvingly quotes Churchill's belief that "Since sectors of the SEATO front were so varied in place and conditions, he [Churchill] felt it best to operate nationally where possible." 45

It is important to note, however, that different perceptions of threat were tied to questions of identity. As Dean Acheson saw it, the threat to which NATO responded was posed "not only to our country but also to the civilization in which we live." "To understand this threat," Acheson continued, one had to "go back more than 2000 years, to the very beginning of Western civilization." "46 Or as Undersecretary of State Robert Lovett put it, the "cement" of the treaty "was not the Soviet threat, but the common Western approach and that Western attachment to the worth of the individual." 47

It is evident that different threat perceptions often frustrated U.S. officials throughout the SEATO negotiations. One U.S. State Department official complained that Asian states were "preoccupied" with internal problems and "distracted" by memories of colonialism. Thus "the idea that Communist imperialism is the immediate and major threat has been slow in taking hold." 48 Secretary Dulles bemoaned the fact that "the countries which had won or were winning their independence from Western colonialism or Japan were often more concerned with past dangers ... than the threat of new peril." 49 Historical enmities, colonial legacies, and newly won state sovereignties affected how Asian elites viewed the communist threat in Asia. In contrast to the Manichean vision of U.S. decision makers, Asian elites confronted a welter of relevant social facts rooted in the perception of self and other.

A direct line from a certain type of threat (cross-border Soviet attack) to a particular institutional form (multilateralism) cannot be drawn in Europe. The European situation after World War II, similar to the situation in Asia, was also complicated. In the early days of NATO the United States neither expected nor feared a massive Soviet assault. U.S. officials saw the creation of NATO as a political move that bolstered the morale of European governments and thus helped them deal with their internal troubles, and as a means of reassuring other European states against any resurgence of a threat from Germany. ${ }^{50}$

Consider also the development of these two alliances over time. While the multilateral nature of NATO grew over time with the perceived probability of a potential Soviet attack in Europe, the increased salience of cross-border conflict in Asia failed to have the same impact on U.S. relations with its Pacific allies. The

44. Ibid., 1023-24.

45. Eisenhower $1963,368$.

46. Jackson $2001,429-30$.

47. Reid 1977, 133.

48. Murphy $1954,516$.

49. Dulles 1954, 743.

50. Gheciu 2001. 
Korean War in particular intensified U.S. threat perception of the Soviet Union's role in Europe. NATO's military buildup and German rearmament became a political option only after the onset of military hostilities on the Korean peninsula. In Asia, by way of contrast, the Korean War failed to spur any move toward increased multilateralism. Indeed, the two states most at risk of a cross-border threat from China (South Korea and Taiwan) were explicitly kept outside of SEATO. ${ }^{51}$

These different responses raise a difficult problem for those who see a direct relationship between a particular type of threat and a specific institutional response. Why does a conventional war (as the United States saw it) in Korea lead to a multilateral response in Europe, but not in Asia, the actual location of the fighting? Despite Soviet caution in Europe, a conventional war in Asia acts as a catalyst for the growth of multilateral security arrangements in Europe, but fails to have the same effect for U.S. alliance efforts in Asia. Similarly, when the United States in the 1960s interpreted the Vietnam War as a conventional cross-border attack, it too failed to spur the growth of multilateral alliance arrangements in Asia.

Had the threat of a massive Soviet assault on Europe never developed, and had the Soviet threat remained entirely one of internal subversion, NATO certainly would have remained a much weaker organization than the one that has developed. The question, however, is whether it is the nature of this cross-border threat that can explain the U.S. preference for multilateralism in Europe. Fortunately, there is no reason to rely purely on counterfactual speculation to answer this question. As the implementation of the Marshall Plan illustrates, the United States preferred to operate multilaterally in Europe even when the Soviet threat was seen as one of internal subversion rather than cross-border attack. In brief, whether the threat was one of internal subversion or cross-border assault, the United States preferred to operate multilaterally in Europe and bilaterally in Asia.

Following Stephen Walt's classic treatment, threat is frequently invoked in realist and liberal analyses. ${ }^{52}$ Yet Walt's theory of threat is a major departure from neorealist theory and pushes beyond rationalist styles of analysis. Specifically, in his analysis Walt moves a large distance from material capabilities to ideational factors. In his analysis, ideology is a variable that competes with others for explanatory power. Ideology is a system of meaning that entails the distinction between self and other in the definition of threat. The cost calculations that states make when they weigh ideological solidarity against security interests are thus not exogenous to their ideological affinities. Hence the threat perception of enemies is an explanatory variable that does not offer a compelling answer as much as it invites further investigation. $^{53}$

Explanations stressing differences in the great power status of European and Asian states or efficient institutional responses to the nature of the communist threat in Europe and Asia share an emphasis on the causal importance of identity-as a

51. U.S. Senate 1949, 56-59.

52. Walt 1987.

53. Katzenstein 1996a, 27-28. 
certain kind of power and as a specific kind of enemy. The following section builds upon and fleshes out these related explanations to provide a fuller account of the way collective identity helped create regional configurations in Europe and Asia that, respectively, included and excluded the United States.

\section{Regions, Identification, and Institutional Form}

A border, argued Georg Simmel, is not a geographic fact that has sociological consequences, but a sociological fact that takes geographic form. ${ }^{54}$ The same can be said of regions. Neither the North Atlantic nor Southeast Asia existed as geographical facts. Both were politically constructed. ${ }^{55}$

The policy of the United States regarding the organization of both regions is puzzling. From a realist perspective, the U.S. preference for multilateralism in Europe after World War II is quite surprising. As Steve Weber notes, a hegemon can maximize its bargaining leverage by forging a series of bilateral deals with its allies rather than tying its hands in a multilateral framework. ${ }^{56}$ Conversely, liberals would probably find the U.S. preference for bilateralism in Southeast Asia after World War II the greater puzzle. As Anne-Marie Burley notes, multilateralism is "the form to be expected from a set of international regimes established by a liberal state." satisfactory explanation must account for both U.S. choices.

The effects of collective identity are an important ingredient to any such explanation. The institutional forms the United States favored in Europe and Asia during the early Cold War were shaped by the different levels of identification that U.S. policymakers had with these newly constructed regions. Identification, as Martha Finnemore notes, "emphasizes the affective relationships between actors" and "is an ordinal concept, allowing for degrees of affect as well as changes in the focus of affect." ${ }^{, 58}$ An argument about the importance of identification in driving U.S. policy in these two regions is consistent with what is perhaps the dominant psychological theory about group identity and its effects-social identity theory. ${ }^{59}$ Once people identify themselves as part of a particular group, studies of social identity have found, they treat members of that group very differently than those outside the group. For instance, when people distribute gains within a defined group, they tend to look more toward maximizing absolute gains; in dealing with outsiders they tend to focus more on relative gains and maximizing the differential between insiders and outsiders. ${ }^{60}$ These findings have been consistent across studies even with the flimsiest and most arbitrarily defined groups. In short, identification is the mechanism that helps connect the construction of specific regional groupings in

54. Gienow-Hecht 2000, 488.

55. See Lewis and Wigen 1997; and Polelle 1999.

56. Weber 1991, 5-9.

57. Burley 1993, 145 .

58. Finnemore 1996, 160

59. See Tajfel 1978; Tajfel and Turner 1986; and Prentice and Miller 1999.

60. Mercer 1995, 239-40. 
Europe and Asia to particular institutional features - multilateral or bilateral-of particular military alliances.

Looked at from the perspective of social identity theory, U.S. policies in both regions become less puzzling. Once the North Atlantic was constructed as a region that put the United States in a grouping of roughly equal states with whom it identified, multilateral organizing principles followed closely. As Ernest Bevin, the British foreign minister put it, bilateral relations imposed by the strongest power, similar to what the Soviets were doing in Eastern Europe, are "not in keeping with the spirit of Western civilisation, and if we are to have an organism in the West it must be a spiritual union ... it must contain all the elements of freedom for which we all stand." ${ }^{\prime 61}$ U.S. policymakers agreed, believing that the Europeans could be trusted with the additional power a multilateral institution would give them and that the Europeans deserved this increased influence.

Lacking strong identification, the United States did not, however, apply the same liberal principles when it came to organizing the newly created Southeast Asian region. Once Southeast Asia, in the view of U.S. policymakers, was constructed as a region composed of alien and, in many ways, inferior actors, bilateralism followed closely. U.S. policymakers did not believe that the Southeast Asian states could be trusted with the increased influence a multilateral institution would offer, nor was there any sense that these states deserved such a multilateral structure.

What was the basis for the identification of the United States with Europe and the lack thereof in its relations with Asia? The available evidence is relatively sketchy and permits only cautious inferences. In their identification with Europe, U.S. officials typically refer to religion and democratic values as the bedrock of a North Atlantic community. A common race is mentioned, though less often, perhaps because Germany's genocidal policies in the 1940s had thoroughly delegitimated that concept in European political discourse. ${ }^{62}$ Perceived affinities of various types reinforced the political trust rooted in common democratic political institutions, "we-feeling," and "mutual responsiveness" that Karl Deutsch and his associates have described as central ingredients of the emergence of a North Atlantic security community, defined by the existence of dependable expectations of peaceful change. ${ }^{63}$ In the case of Asia, these various affinities and trust were absent, religion and democratic values were shared only in a few cases, and race was invoked as a powerful force separating the United States from Asia. The U.S. preference for multilateral or bilateral security arrangements followed from these different constellations.

The Origin of the North Atlantic Community. The creation of the political concept of the North Atlantic community is an excellent example of the process of identification at work in U.S. politics as well as a demonstration of how

61. Jackson $2001,428-29$.

62. See Horne 1999, 454-59; and Hunt 1987, 161-62.

63. Deutsch et al. 1957. 
issues of identity are entwined with material factors and instrumental political calculations. The emergence of a North Atlantic region followed a dramatic change in the prevalent image of the United States' place in the world that occurred during World War II. Before the war, Alan Henrikson argues, maps were typically drawn with the United States in the center surrounded by two oceans. However, the efforts to resupply Great Britain and to later transport large numbers of troops to Europe caused a change in that cartographic and cognitive image. During and after the war, more and more maps appeared that put the Atlantic in the center with the United States and Europe positioned on opposite sides. During World War II, the Atlantic association thus became more natural. ${ }^{64}$ The shift to a "North" Atlantic focus was given a boost after 1945 when the Soviet Union pressured Norway to sign a defense pact. Had the Soviet Union established a zone of influence over Norway it would have gained a large window on the Atlantic and thus exposed Europe's northern flank. ${ }^{65}$

The creation of the new geographic category of "North Atlantic" also served clear political ends and was in some ways the product of calculated political agency. Martin Folly, for example, argues that "the idea of a North Atlantic system was a stroke of genius" on the part of Ernest Bevin. ${ }^{66}$ In the early 1940s, the British government embarked on a political strategy aiming to prevent a disengagement of the United States from Europe after the end of the war. Bevin recognized that the United States would hesitate to join a "European" alliance, but would feel much more comfortable talking about sea-lanes, access to bases, and a "North Atlantic" alliance. A North Atlantic focus meshed nicely with the U.S. military's concern with "stepping stones" across the Atlantic. Reliant on bases and stopping-off points for the transportation of troops and equipment across the Atlantic, the armed services' emphasis on the importance of Iceland, Greenland, and the Azores also put the Atlantic in the foreground. ${ }^{67}$ In U.S. domestic politics, the focus on a North Atlantic community had a two-fold advantage. It promised to be an easier sell to an electorate and a Congress wary of European entanglements; ${ }^{68}$ furthermore, the concept of 'community' established a basis for identification that transcended military-strategic considerations.

Terminological innovation also suited Canada. Seeking to minimize bilateral dealings with the United States, Canada opposed any sort of "dumbbell" shaped arrangement combining a North American and a European pole. A North Atlantic arrangement would allow Canada to use the European states as a balance against the United States. It would also allow the Canadian government to portray its concessions to the alliance as concessions to a North Atlantic group of states and not solely

64. Henrikson 1975.

65. Henrikson 1980.

66. Folly 1988, 68.

67. See Lundestad 1980, 251; and Henrikson 1975 and 1980, 19.

68. Kaplan $1984,2-3,7-8,10,31,41-42,52,70,78,115-17$. 
as concessions to the United States. In short, a North Atlantic community meant that Canada did not have to deal with the United States alone. ${ }^{69}$

It is important to note that this geographically defined category constrained, but did not determine membership. If geography is destiny, the inclusion of Italy, "unwashed by Atlantic waters," in NATO was clearly an anomaly. ${ }^{70}$ So was the subsequent accession of Greece and Turkey. Even after George Kennan acquiesced in the creation of a North Atlantic treaty, he continued to oppose Italy's participation. Only by limiting the treaty to a strict geographic area, Kennan reasoned, could the United States avoid provoking the Soviet Union and offending other allies by their exclusion. As Kennan saw it, "the only sound standard for membership in the Atlantic Pact was indeed a geographic one."71 While the administration readily conceded that Italy was not in the North Atlantic, it continued to support Italy's inclusion because it was too important to Atlantic defenses to be left out. ${ }^{72}$ Italy's inclusion among NATO's founding members, along with that of undemocratic Portugal (given the strategic importance of the Azores), underscore the importance of eclectic explanations that encompass both strategic calculations and regional identities. In these two cases, the geographically defined region and the sense of identification with fellow democracies proved less decisive than strategic calculations in determining membership. Italy's membership ended up being consequential, however, because even as it violated "the 'natural' geographic basis of the North Atlantic, it had the subtle effect of extending the Atlantic concept itself to eventually include both the Western and the Eastern Mediterranean. ${ }^{73}$

In 1948, official and public discourse regarding Europe saw a major and sudden change. Before March 1948, a possible transatlantic alliance was invariably discussed under the rubric of a European or a Western European alliance. After March 1948, however, the focus of official discourse, as reflected in the documents produced at the time, shifted radically to an Atlantic or North Atlantic treaty system and community. The public discourse, as indicated by the coverage of the New York Times, underwent a similar transformation in late 1948. For example, in the editorial cartoons offered in the "Week in Review" section, the graphical opponent of the Soviet Union changes from Europe, to Western Europe, to the West, and finally, by December 1948, to the North Atlantic and NATO. The relatively sudden emergence of this "North Atlantic" focus demonstrates that new regional identities can emerge quickly if suitable material and ideational raw materials are available.

Considering the rapidity of this shift to a North Atlantic focus, it is noteworthy that U.S. State Department officials insisted that the signatories of the treaty did not invent the North Atlantic region. They maintained instead that the treaty merely codified a political community that had been in existence for centuries and that

69. Reid 1977, 102-10, 131-32.

70. Lundestad 1980, 242.

71. Kennan 1967, 411-12.

72. See Acheson 1969, 279; and Truman 1956, 248-50.

73. Henrikson 1980, 19-20. 
provided the basis for mutual identification. In the words of Dean Acheson, NATO was "the product of at least three hundred and fifty years of history, perhaps more." 74 Yet, for all the stress on the reality and long history of the region, prior to 1948, with the exception of a few references to the International Civil Aviation Organization, State Department officials never talked about a North Atlantic region. Like geography, history was not destiny.

The Origins of Southeast Asia. Southeast Asia as a particularly defined region has also had a relatively brief history. Before World War II, the region had been known by a number of different names. Some divided the area into Chineseinfluenced Indochina, the Spanish-influenced Philippines, and those areas strongly influenced by Indian culture. Among European and U.S. diplomats, the region was often seen as an extension of either China or India and referred to as "further India," "greater India," "Indo-China," or "the Far Eastern tropics." The popular term in Japan was "Nan-yo" (southern seas) and in China either Nan-Yang or Kun-Lun ("Little China" or "the lands of the Southern Ocean"). ${ }^{75}$

The rise to prominence of the term "Southeast Asia" came with Japan's occupation of the area during the Pacific War. The term emerged to designate the areas south of China that fell to Japanese occupation. ${ }^{76}$ The private correspondence between Roosevelt and Churchill during World War II reflects the gradual emergence of this regional designation. A first mention came in early 1941 when Roosevelt wrote about Japan's proposal to forgo any armed advance into the "Southeastern Asiatic" area, provided the United States made a similar pledge. Roosevelt further explained to Churchill that the U.S. response was to simply warn Japan against taking any military moves in "South-East Asia." 77

After the United States entered the war and decided to concentrate first on the European theater, discussion of the region faded. When attention shifted back to the Asian theater, what to call this region remained undecided. Churchill wrote in June 1943 that it was time for the Allies to think more about "the South East Asia (or Japan) front," and he recommended the creation of a new command for that region. Later, Churchill reiterated this call, but now denoted the envisioned entity as "a new command for East Asia." Here, practical political calculations heavily influenced the naming process as Roosevelt rejected Churchill's call for a unified East Asian command, arguing that creating such a command would alienate Chiang Kai-shek, who controlled the China theater. To avoid such an offense, Roosevelt moved the focus back to "South-East Asia." Churchill accepted Roosevelt's worries about offending China and agreed that "perhaps it would be desirable to give the new command the title of 'South-East Asia' instead of "East Asia'." 78 At the Quebec

74. Acheson 1949, 385.

75. See Sar Desai 1997, 3; Williams 1976, 3-5; and Warshaw 1975, 1.

76. See Williams 1976, 3; and Warshaw 1975, 1.

77. Kimball 1984, 1:275-76.

78. Kimball 1984, 2:248, 263, 275-77, 282. 
conference in August 1943, the United States and Great Britain agreed to create a Southeast Asian Command (SEAC). SEAC's area of responsibility corresponded roughly to what today is conventionally called Southeast Asia.

After the victory of communist forces in China, the hands-off policy the United States had adopted after the Pacific War shifted quickly. In Andrew Rotter's words, the Truman administration " discovered' Southeast Asia at the intersection of its policy toward China, Japan, Great Britain, and France."79 Bolstering pro-Western forces in the region could help contain China, restore Japan's economy, strengthen Britain, and halt the bleeding of France. U.S. policy became "regionalized." "American policy makers," writes Rotter, "no longer regarded Southeast Asia as a disparate jumble of unrelated states, but as a region that had to be tied to the most important independent nations of the Far East and Western Europe." 80 SEATO, established in September of 1954, should be seen as an extension of this regionalization and the political attempt at tying the region to the rest of the world. Only two of SEATO's members, Thailand and the Philippines, were geographically part of Southeast Asia. The other six members (Australia, France, Great Britain, New Zealand, Pakistan, and the United States) came from outside the region.

The inclusion of France and Great Britain and, to a lesser extent, Australia and New Zealand in SEATO raises a number of interesting issues. In one sense, it shows the importance of a sense of identity in forming alliances. As the United States endeavored to construct alliances outside of Europe, it sought the cooperation of European states even as European colonialism was collapsing in Asia. With Great Britain and France in the alliance, however, why not work multilaterally with them as the United States did with NATO? The answer to this question points to the malleability of identity - a source of weakness for explanations that focus only on identity. Looking to the post-war world, Franklin Roosevelt initially had hoped to work with China rather than European colonial powers, in bringing stability to Asia. When the victory of communist forces in China made that course impossible, the United States turned reluctantly to the European colonial powers as a distinctly second-best solution. Here is one area where the U.S. identification with its European allies broke down. The U.S. government was unwilling to identify itself too closely with the colonial practices of the European states in Asia; this limited the degree to which the United States wanted to work multilaterally with the European states in Asia. The pliability of this sense of identity-America is like the Europeans in Europe, but not like the Europeans in Asia—shows the limitations of explanations that focus only on collective identity and underlines the advantages of eclectic explanations.

NATO and SEATO. Based on civilizational, ethnic, racial, and religious ties as well as shared historical memories, identification with Europeans rather than with 
the peoples of Southeast Asia was considered to be quite natural. These different levels of mutual identification are an important cause of the different institutional forms that the United States favored for its alliances in Europe and Asia during the early Cold War.

One of the most striking aspects of the discussions surrounding the formation of NATO is the pervasive identification of the United States with Europe. This aspect is exemplified by the strident assertion that the North Atlantic already existed as a political community and that the treaty merely formalized this pre-existing community of shared ideals and interest. ${ }^{81}$ In political debates in the United States, one found constant references to a "common civilization," a "community," a shared "spirit," "like-minded peoples," and "common ideals." 82 As W. Averell Harriman put it, "there is a spiritual emotion about this which is hard to emphasize . . free men are standing shoulder to shoulder." 83 Even while criticizing the Truman administration's overall policies, the columnist Walter Lippman argued that the members of the "Atlantic Community" are "natural allies of the United States." The "nucleus" of this community, according to Lippman, is "distinct and unmistakable" based on geography, religion, and history. ${ }^{84}$ The rhetoric of the United States' European allies similarly referred to a "spiritual confederation of the West," protecting "Western bastion[s]," "the virtues and values of our own civilization," and how the "North Atlantic Community is a real commonwealth of nations which share the same democratic and cultural traditions." 85 This sentiment found ultimate expression in the preamble of the NATO treaty, which affirmed the determination of the members "to safeguard the freedom, common heritage and civilization of their peoples."

Identification had an undeniable racial component. For example, former U.S. Assistant Secretary of State Will Clayton hoped that NATO could be the first step in the formation of an Atlantic Federal Union. In his testimony in support of NATO, Clayton explicitly linked his support of closer U.S. and European relations to racial grounds in addition to cultural ones. He argued that "my idea would be that in the beginning the union would be composed of all countries that have our ideas and ideals of freedom and that are composed of the white race." 86

In part because Americans identified strongly with Europeans, Europe was also judged to be a strong ally. Indeed, strong identification with Europe led the United States to consistently give very high and favorable estimates of the strength of its European allies. ${ }^{87}$ Throughout the Cold War, U.S. officials distinguished their NATO partners from other alliance members. Europe was seen as a "center of world power" populated by a "vigorous" people who had been powerful in the past and

81. Hampton 1995.

82. See U.S. Senate 1973, 87, 344; and U.S. Senate 1949, 15, 197, 292.

83. U.S. Senate 1949, 206.

84. Jackson $2001,320-21$.

85. See Jackson 2001, 427-28; and Gheciu 2001, 3-5.

86. U.S. Senate 1949, 380.

87. Urwin 1995, 14. 
would be again in the future. ${ }^{88}$ Looking at what he called the "great industrial complex of Western Europe," President Eisenhower believed that America's Atlantic allies could not long remain intimidated by " 190 million backward" Russians. Speaking specifically about the Eisenhower administration's plan to create a multilateral nuclear sharing arrangement within NATO, Dulles argued that a unilateral U.S. nuclear guarantee could not be "a sound basis for a major country's security" and that he simply could not "contemplate a situation in which there were first and second class powers in NATO." 89

The United States' reaction to the formation of SEATO was very different. U.S. debates show hardly a trace of identification, and there are no equivalent statements of shared ideals or future visions of the Asian allies as great powers. Indeed, it is the differences, not the commonalties, in civilization, race, ethnicity, religion, and historical memories that lead to the articulation of strong doubts about the current and future strength of these nations as parts of an Asian alliance. Even as colonialism was ending, the colonial mindset remained strong. This outlook stemmed in large part from the personal backgrounds of the men who dominated the U.S. foreign policy machinery after World War II. Drawn from elite New England prep schools, Ivy League universities, and Wall Street businesses and law firms, the so-called "Eastern Establishment" was then in its heyday. These men, alternating between their private and public sector careers, switching positions "like lines in a hockey game changing on the fly," ventured into the post-World War II world with a European and even an Atlantic bias. ${ }^{90}$ Having "grown up and succeeded in a world marked by European power, Third World weakness, and nearly ubiquitous racial segregation," they could accept such distinctions between Europeans and others without question. ${ }^{91}$ Interestingly, when these men attempted to explain what they saw as the more alien and difficult to understand behavior of the Soviet Union, they invariably stressed the "Asiatic" or "Oriental" nature of the regime. ${ }^{92}$ As Senator James Eastland viewed the nascent Cold War, it was a struggle between "eastern and western civilization," a battle between "the Oriental hordes and a western civilization 2,000 years old." 93

A multilateral approach in Europe also allowed American politicians to evade the potentially delicate challenge posed by different ethnic voting blocs in the United States. With large numbers of Americans tracing their ancestry to different European countries, attempting to play favorites or to make distinctions among these states in American foreign policy would be a risky strategy for elected politicians if these distinctions upset significant ethnic voting blocs. By treating all European allies the same, multilateralism offered a solution to what could otherwise have been

88. See Jackson 1967, ix; and U.S. Senate 1949, 192.

89. Trachtenberg 1999, 147, 177, 194, 197, 210.

90. Isaacson and Thomas 1986, 19-31, 428.

91. Borstelmann 1999, 552.

92. See ibid., 552--553; and Isaacson and Thomas 1986, 306, 320.

93. Jackson $2001,293$. 
a tricky balancing act. Since Asian-American voting blocs were less important during the early stages of the Cold War, a similar electoral dilemma did not arise with regard to U.S. foreign policy in Asia. ${ }^{94}$

There were, of course, segments in U.S. society that had more interactions with and material interests in Asia than Europe. Represented mostly by the midwestern and Pacific wings of the Republican party, these individuals called for an "Asiafirst" strategy after Pearl Harbor and continued to criticize U.S. foreign policy into the Cold War for paying too little attention to Asia. Part of the attention they gave to Asia was driven by their desire to criticize the European-focused Eastern Establishment that dominated the Democratic Party, the presidency, and the foreign policy apparatus of the U.S. government. A large part of this attention, however, was also driven by the commercial links Western businesses had forged across the Pacific and the large number of American missionaries who had gone to Asia. ${ }^{95}$

Why did the preferences of American elites looking to Europe prevail over those of the Asia-firsters? In keeping with our emphasis on the need for eclectic explanations, we find that the answer lies in a combination of identity and material factors. Identifying with Europe, the Eastern Establishment not only had a preference for cooperating with and focusing on Europe, it also controlled the institutional means of power within the United States to implement such a foreign policy. The European-firsters had political clout as "the foreign policy center was owned by the Establishment ... largely from the northeastern part of the United States." 96 And the United States had "a tradition of selecting foreign service officers from the Ivy League, and secretaries of state and treasury from Wall Street." ${ }^{, 97}$ In addition, a large number of the foreign service officers that did specialize in Asian affairs were purged from the government as a result of the McCarthy Red Scare following the fall of China.

Although represented by powerful figures on the American political scene, like Senator Robert Taft of Ohio and publishing magnate Henry Luce, himself the son of Asian missionaries, Asia-firsters were never as influential as their Eastern Establishment rivals. ${ }^{98}$ Furthermore, the opposition Republicans were split on the issue of a European versus an Asian focus, with the northeastern wing of the party solidly in the European-first camp and the midwestern wing of the party torn on the issue. Indicative of this split is the well-noted conversion of Senator Arthur Vandenberg of Michigan to support of Truman's foreign policy, especially NATO. This conversion was, in part, a result of an administration strategy, as Paul Nitze put it, "to build up Senator Vandenberg, as opposed to Senator Taft, and create a split within the Republican Party, and to drive our policy in between these two poles." 99

94. See Cowhey 1993; and DeConde 1992, 148-151, 194.

95. See Westerfield 1955, 240-68; and Purifoy 1976, 49-73.

96. Destler, Gelb, and Lake 1988, 22.

97. Cumings $1990,95$.

98. Cohen 2000, 177-80.

99. Fordham 1998, 370. 
This strategy was favored, no doubt, by the growing international interests and the political influence of the auto industry centered in Detroit. ${ }^{100}$ Eisenhower's victory over Taft in the Republican presidential primaries in 1952 indicated and solidified the triumph of the internationalist (and Europeanist) wing of the Republican party.

In explaining why one set of ideas triumphs over another, many analysts have pointed to the importance of the "ffit" between any particular idea and the general ideological context, existing political institutions, and pressing political concerns. As Mark Laffey and Jutta Weldes note, however, fit does not simply exist; instead it is made by political actors. ${ }^{101}$ Indeed, the stridency with which proponents of NATO stressed a pre-existing community and common civilization can be seen as part of a deliberate construction of "fit," drawing on both identity and material factors. A European strategy proved an easier sell to a nation that saw itself as an offshoot of Europe and whose levers of power were in the hands of men who identified closely with Europeans. In addition, strong economic links between the United States and Europe provided ample material incentives.

Although the European- and Asia-firsters disagreed over which region more deserved American attention and resources, it is important to stress that this disagreement did not involve a debate over multilateral or bilateral forms of international cooperation that the United States should adopt in these regions. This is most clear when one examines how Asia-firsters thought about their preferred policy in Asia. Their commitment to Asia did not extend to a willingness to pursue a multilateral path in that region. Their interactions with Asians, especially as part of Christian missionary work, did not lead to the development of a sense of identity with Asian peoples that could serve as a basis for a multilateral institution. The exact opposite occurred. Part of what made dealing with Asians rather than Europeans attractive to Asia-firsters was the sense that backward Asians could still be saved under American tutelage. ${ }^{102}$ Asians were viewed as "barbarian but obedient," and Asia was thought of as "a region of vast resources and opportunities, populated by dutiful and cringing peoples who followed white leadership." The goal was not multilateral cooperation among equals (or even semi-equals), but one of unilateral U.S. dominance. ${ }^{103}$ The case of the Asia-firsters demonstrates the indeterminacy of arguments linking perceived interests and threats to particular institutional forms without consideration of collective identity. Even those Americans who saw U.S. interests more tied to Asia than to Europe, and who believed that the Cold War would be fought and won in Asia, did not reach for a multilateral framework for cooperation in this region. The belief that Asians were not only foreign, but also inferior, helped push these individuals to support unilateral or bilateral, rather than multilateral, policies in Asia.

100. Cumings 1990, 38, $92,97$.

101. Laffey and Weldes 1997, 202-203.

102. See Cohen 2000, 179; and Purifoy 1976, 51.

103. Cumings 1990, 97, 93, 79-97. 
When issues of identification, trust, and power arose with regard to SEATO, they did so in the context of explaining. why Asian allies could not have, and did not deserve, the same privileges that had been given to the European allies. After signing a bilateral treaty with Japan, John Foster Dulles explained that, in the absence of identification, there could be no Asian equivalent of NATO. At the same time, however, he included Japan and the Philippines on the list of nations with which the United States shared a common destiny. ${ }^{104}$ This indicates both the diversity of sources and the varying strengths of U.S. post-World War II identifications. Even though Japan and the Philippines were situated outside of what Dulles saw as a Western "community of race, religion and political institutions," shared historical experiences (the war and subsequent occupation of Japan and the colonization of the Philippines) could provide some basis for identification with particular Asian states. Identification is a matter of degree, not an all-or-nothing proposition. If race, religion, and shared political institutions helped to put the United States' European allies in a class ahead of its Asian allies, shared historical experiences similarly helped put certain Asian allies ahead of others.

There is a strong note of condescension in many of the U.S. discussions of SEATO; this condescension did not exist with regard to NATO. Many American policymakers did not see Asians as ready or sufficiently sophisticated to enjoy the trust and the same degree of power that the United States had offered to European states. In one particularly vulgar example, in the context of possible economic aid to the Philippines, one U.S. State Department official explained that the United States had to closely supervise the use of such aid, because as he saw it, they "were only one generation out of the tree tops."105

The denigration of the importance of Asia and the skill of Asians reached the highest levels in the U.S. State Department. While Dean Acheson was secretary of state he visited Europe at least eleven times, claiming at the same time to be too busy to make even a single visit to East Asia. With the outbreak of war on the Korean peninsula in June 1950, Acheson decided to actively support U.S. involvement in the war primarily to demonstrate American credibility to its new European allies. With regard to the later war in Vietnam, Walt Rostow attributed Acheson's eventual opposition to American involvement to the former secretary of state's calculation that it was "too much blood to spill for those little people just out of the trees." Later in his career, while reflecting on his overall approach to Asians, Acheson maintained that "l still cling to Bret Harte's aphorism, 'that for ways that are dark/And for tricks that are vain/The Heathen Chinese is peculiar.' But no more so than the heathen Japanese. $" 107$ Acheson was hardly alone. An even blunter example of America's condescension toward its potential allies in Asia can be found in a State Department memo discussing the possibility of forming a general Pacific Pact:

104. Dulles 1952, 183-84.

105. McMahon 1999, 58.

106. Isaacson and Thomas 1986, 506-507, 648, 698 .

107. Horne 1999, 457. 
The plain fact is that any exclusive Western joint action in Asia must carry with it the clear implication that we do not take the Asians very seriously and in fact regard them as inferiors. We shall not be able to avoid this implication because that is indeed our attitude. ${ }^{108}$

The difference in identification and the different U.S. policies followed in Asia and Europe after World War II were not an aberration. In many ways, they were a continuation of U.S. wartime attitudes that led to a "Europe first" strategy; the internment of Japanese-Americans; a greater degree of hatred regarding America's Asian enemies (the Japanese) as opposed to European opponents (usually the Nazis rather than the Germans); and the basic decision, even before the war in Europe was over, to use the atomic bomb against Japan first, not Germany. ${ }^{109}$ Indeed, as Michael Hunt has argued, there is a long tradition in U.S. foreign policy of dividing the world into a racial hierarchy, with the United States and Great Britain at the top, followed by other European peoples, and with Asians, Latinos, and Africans further down the list. ${ }^{110}$ While overtly racial categories became less prominent over time and have been replaced in U.S. rhetoric, in recent decades, with allusions to cultural and civilizational values, the basic hierarchy has remained the same. The men in charge of handling the United States' post-World War II foreign policy were no exceptions. Franklin Roosevelt likened "the brown people of the East" to "minor children ... who need trustees." Similarly, Harry Truman's private writings often lavished great praise upon the British, while speaking dismissively of "Chinamen" and "Japs." President Eisenhower placed "the English-speaking peoples of the world" above all others. As one of his advisers put it, "the Western world has somewhat more experience with the operations of war, peace, and parliamentary procedure than the swirling mess of emotionally super-charged Africans and Asiatics and Arabs that outnumber us." "11

U.S. decision makers' ready identification with Europe and the perception of Europe as belonging to the same political community as the United States helped, together with material and instrumental factors, move the United States to favor multilateralism in Europe. The weakness of identification with Asia and the belief that the Asian countries belonged to a different and inferior political community led to a U.S. preference for bilateralism in Asia.

\section{Conclusion}

The origin of the North Atlantic and Southeast Asian regions, as well as their institutional forms, disclose a great deal about the shape and shaping of world politics. In this article, we have not explored all empirical and analytical aspects of

108. U.S. Department of State 1984, 262.

109. See Dower 1986; Makhijani 1995; and DeConde 1992, 118.

110. Hunt 1987, 46-91.

111. Ibid., 162-64. See also Lauren 1988. 
this process. For example, we do not investigate fully the effects that the policies of the European and Asian states had on U.S. foreign policy or the relationship between institutional form and the success or failure of particular alliances. In addition, there remains a great deal of potentially valuable historical material that could shed further light on the development of these regions and the historical variation of the United States' level of identification with them beyond the snapshot focus of the post-World War II years discussed here.

Furthermore, analytical eclecticism leaves room for disagreement about the shape of particular causal arguments and the sequence in which variables interact. While instrumental rationality and identity as well as material and social factors are intertwined, the particular combination of these factors in various concrete situations need not be the same. In the aggregate, these "explanations are complementary rather than mutually exclusive, may be hard to distinguish empirically, and in some cases there might not even be any fact of the matter to distinguish at all." 112 The strident insistence on the existence of a North Atlantic community, for example, and the quickness with which that concept was embraced by U.S. policymakers suggest that in Europe, the invocation of a North Atlantic collective identity probably played an instrumental role in a situation in which the building blocks for a multilateral security arrangement were more readily available than in Asia. Members of the executive branch and the United States' potential allies were after all trying to do everything to rally a skeptical public and Congress to the arduous task of a prolonged engagement in Europe. This is not to deny, however, that those building blocks included, besides material factors, ideational ones such as a sense of shared Western, European, white, or democratic cultures. ${ }^{13}$ Similar ideational raw materials did not exist in Asia, making any construction of a regional identity there far more difficult. References to civilizational and racial differences with Asia were offered and accepted as a matter of fact. This suggested that it was these ideational differences, not simply the material consequences of international anarchy, that must be taken into account in a compelling explanation of how and why U.S. decision makers defined the interests that informed their policy choices. NATO and SEATO thus were not natural objects reflected only in the material realities of geography. Political actors constructed them through the instrumental political objectives of potential member states (balancing U.S. preponderance in NATO in the case of Canada, for example, or tying the United States to Europe on a long-term basis in the case of Britain) and through the invocation of unquestioned ethnic or racial identities (in U.S. domestic debates).

The causal structure of eclectic arguments need not be uniform. Such arguments refuse to grant primacy to any one analytical construct or paradigmatic orientation. We argue for the treatment of culture as a focal point to solve the problem of indeterminacy in games of strategic interaction, culture as a source of information 
for sending and receiving signals, and culture as a source of symbolic resources to be deployed in domestic political battles. We go beyond these productive ways of thinking about culture by also focusing on culture's relevance to constitutive processes, that is, to the creation and recreation of collective identities. Rationalist theories of culture that highlight focal points, information, and resources neglect the importance of constitutive processes. Many strands of constructivist theory make the opposite mistake. They elevate constitutive processes a priori above all other causal influences. In this paper, we seek to develop a third, eclectic stance that grants constitutive processes causal relevance rather than assuming irrelevance or asserting primacy.

A preference for eclectic theorizing contradicts the insistence on paradigmatic purity that typifies important analytical controversies in the field of international relations. A problem- rather than approach-driven style of analysis fits the complexity of political processes that occur within specific contexts. ${ }^{14}$ And it is in full agreement with how theoretically informed research is conducted in other areas of political science and the social sciences more generally. Up to a point, abstract debates can be useful in elucidating ontological, epistemological, and methodological controversies. But it is the identification of empirical anomalies and the construction of disciplined, theoretically informed explanations with particular attention to the specification of causal mechanisms and multiple methods that pushes outward the boundaries of knowledge. One substantial advantage of a problem-driven approach is to sidestep often repetitive, occasionally bitter, and inherently inconclusive paradigmatic debates. While a problem-focused, eclectic style of analysis has many advantages, at this stage of our knowledge it does not, however, permit us to distinguish conclusively between different types of causal chains.

Cultural constructions of U.S. national identity have resisted profoundly all notions that the United States might be anything else "but the transplantation of a European civilization on the North American continent." Within a dominant Anglo-Saxon culture, Asian-Americans have been denied recognition as Americans. From this perspective, "the Pacific contrasts sharply with an Atlantic region. Ties across the Atlantic have derived their perceived cohesiveness ultimately from assumptions about a metahistorical cultural affinity between the United States and Europe. On the other side of the continent ... the same cultural self-image rendered the Pacific an alien territory, peopled by alien cultures that must be overcome." 115 Multilateralism in Europe and bilateralism in Asia flowed naturally from this construction of U.S. collective identity.

Explicitly considering the role collective identities play in world politics can help advance our theoretical and empirical understanding of international relations. Collective identities matter because they help shape the definition of the actors'

114. Jervis 1997.

115. Dirlik 1993, 315-16. See also DeConde 1992, 10-26, 50-52, 158-159, 193-194; and Skrentny n.d., 78-87. 
interests. An eclectic stance suggests that rationalist theories are more compelling when they are combined with constructivist insights into the importance of norms and identities, as is true of explanations focusing on great power status and the presence or absence of threat. In the 1990s, for example, rationalist theories that are eclectic in seeking to incorporate central insights of constructivism speak of the advantages and disadvantages of strategies of "self-binding." Reflecting purposive political choices, self-binding may look advantageous from a liberal perspective. It prolongs U.S. hegemony by lessening the threat the United States poses to others and eliminating the balancing process against the United States by lesser states. ${ }^{116}$ In these explanations, however, the distinction between self and other remains undertheorized, and the effects of self-binding remain relatively weak. From a realist perspective it is inexplicable why a strong state would choose to pool its sovereignty in the interest of setting credible limits to the unilateral exercise of power, as Germany did in supporting economic and monetary union. ${ }^{17}$ Strategies of self-binding cannot be fully understood without analyzing explicitly the content and change in collective identities.

Once a region is formed or once a particular institution is put in place, that construction then has effects on the future of regional and global politics. There is a great deal of path dependency at work. In Europe, Italy's inclusion in NATO underlines the fact that a region that might not be snug and plausible at first may, over time, be regarded as perfectly natural and set an important precedent. It is difficult to conceive how a geographically limited "North" Atlantic community, excluding all the Mediterranean countries, could have been expanded as readily as NATO did in the $1990 \mathrm{~s} .{ }^{118}$ With expansion, however, comes a new danger to NATO's identity as a separate community. As Michael Brenner argues, with the Soviet Union defunct, communism dead, liberal democracy on the march, and NATO expanding eastward, "what then distinguishes the Atlantic partners? What justifies their banding together-as allies, as a diplomatic formation, as a brotherhood?" 119 Looking toward the further expansion of NATO, James Kurth has noted that one of the strongest arguments for allowing the Baltic States into the alliance is precisely because "these countries have represented the easternmost extension of Western civilization." 120

Debates about regional definitions and regional institutions are also occurring in Asia and are similarly influenced by the choices made in the aftermath of World War II. Currently, East Asia and Southeast Asia are beginning to merge, through debates and controversies, as Mie Oba and Susumu Yamakage note, ${ }^{121}$ and through diplomatic initiatives such as the Association of Southeast Asian Nations plus 3

116. See Lake 1999, 262; and Ikenberry 2001.

117. Grieco 1993, 338.

118. Schimmelfennig 2001

119. Brenner 1995, 233.

120. Kurth $2001,15$.

121. Oba and Yamakage 1998, 31. 
process. And Southeast Asia and East Asia are nested in a more encompassing Asian or Asian-Pacific region. It is not clear what to call that larger region because there is no accepted definition of the Asia Pacific Region. Indeed there exists not even a standard convention for writing it. Asia-Pacific, Asian Pacific, Pacific Asia, AsiaPacific, Asia/Pacific, Pacific Rim, and Asia and the Pacific are all used. ${ }^{122} \mathrm{~A}$ collective regional identity cast in a multilateral institutional form, however, has been slower to emerge in Asia than in Europe. Looking to explain this difference, many analysts have pointed to some of the obstacles to multilateralism that were also seen as key during the early Cold War, including cultural diversity, disparate economies, asymmetries in power, and historical animosities. ${ }^{123}$ To these factors we would also add the continuing lack of Asian-Pacific collective identity and the lack of institutional experiences that could have helped provide a sense of community. Undoubtedly spurred by the growing influence of Asian-Americans in the U.S. political process, ${ }^{124}$ in recent years U.S. policymakers have been increasingly calling for the development of multilateral security communities in Asia. As of yet, however, there have been few concrete moves by the United States. Instead of fully embracing multilateralism and a common Asian-Pacific identity, the United States has limited its actions to calls for increased multilateral cooperation among the states of Asia while the United States pursues what the U.S. ambassador to South Korea calls an "enriched bilateralism." While there is much talk of the common interests the United States has with other Asian states, the United States is still far from embracing an identity as a member of an Asian-Pacific community similar to its membership in the North Atlantic community that would be needed to sustain a multilateral commitment. ${ }^{125}$

As this discussion suggests, the United States' sense of identity continues to influence the direction of U.S. foreign policy, in combination, of course, with other factors. For example, recent debates over why the United States chose to intervene in Kosovo but not in Rwanda intimately involve questions of America's identity. When asked about intervening in the former Yugoslavia as opposed to halting genocide in Africa, George Kennan warned against overburdening the United States with commitments but also concluded that "Europe, naturally, is another matter." The United States, Kennan reasoned, had to go after Milosevic because his "undertakings strike at the roots of a European civilization of which we are still largely a part." 126 Whether the growing demographic presence and resulting electoral power of Asian-Americans, Hispanic-Americans, and African-Americans will change this sense of a European-focused American identity or whether these groups will remain in some sense "perpetual foreigners" remains to be seen. ${ }^{127}$ As

122. See Alagappa 2000, 20; and Emmerson 1994, 435.

123. See Duffield 2001, 86-89; Nolt 1999, 96-100; and Simon 1993, 257.

124. Cohen $2000,240$.

125. Blair and Hanley 2001, 7-17.

126. Ullman 1999, 8 .

127. Watanabe $2001,643$. 
the arguments we advance in this article indicate, however, the answer to this question is likely to have a substantial impact on the future of U.S. foreign relations. ${ }^{128}$

\section{References}

Acharya, Amitav. 2000. The Quest for Identity: International Relations of Southeast Asia. Oxford: Oxford University Press.

- 2001. Constructing A Security Community in Southeast Asia: ASEAN and the Problem of Regional Order. London: Routledge.

Acheson, Dean. 1949. Statement on the North Atlantic Treaty. Department of State Bulletin 20 (508):385. 1969. Present at the Creation: My Years in the State Department. New York: W.W. Norton and Company.

Adler, Emanuel, and Michael Barnett, eds. 1998. Security Communities. Cambridge: Cambridge University Press.

Alagappa, Muthia. 2000. Asia-Pacific Regional Security Order: Introduction and Analytical Framework. Paper prepared for the Second Workshop, Security Order in the Asia-Pacific, 29 May-2 June, Bali, Indonesia.

Bix, Hermann P. 2000. Hirohito and the Making of Modern Japan. New York: HarperCollins.

Blair, Dennis C., and John T. Hanley, Jr. 2001. From Wheels to Webs: Reconstructing Asia-Pacific Security Arrangements. The Washington Quarterly 24 (1):7-17.

Borstelmann, Thomas. 1999. Jim Crow's Coming Out: Race Relations and American Foreign Policy in the Truman Years. Presidential Studies Quarterly 29 (3):549-69.

Brenner, Michael. 1995. Conclusion. In Multilateralism and Western Strategy, edited by Michael Brenner, 232-36. New York: St. Martin's Press.

Burley, Anne-Marie. 1993. Regulating the World: Multilateralism and the Projection of the New Deal Regulatory State. In Multilateralism Matters: The Theory and Praxis of an Institutional Form, edited by John Gerard Ruggie, 125-56. New York: Columbia University Press.

Cohen, Warren I. 2000. America's Response to China: A History of Sino-American Relations. 4th ed. New York: Columbia University Press.

Cowhey, Peter F. 1993. Elect Locally-Order Globally: Domestic Politics and Multilateral Cooperation. In Multilateralism Matters: The Theory and Praxis of an Institutional Form, edited by John Gerard Ruggie, 157-200. New York: Columbia University Press.

Cumings, Bruce. 1990. The Origins of the Korean War. Vol. 2, The Roaring of the Cataract 1947-1950. Princeton, N.J.: Princeton University Press.

DeConde, Alexander. 1992. Ethnicity, Race and American Foreign Policy. Boston: Northeastern University Press.

Destler, I. M., Leslie H. Gelb, and Anthony Lake. 1988. Breakdown: The Impact of Domestic Politics on American Foreign Policy. In The Domestic Sources of Foreign Policy: Insights and Evidence, edited by Charles W. Kegley and Eugene R. Wittkopf, 17-29. New York: St. Martin's Press.

Deutsch, Karl W., Sidney A. Burrell, Robert A. Kann, Maurice Lee, Jr., Martin Lichterman, Raymond E. Lindgren, Francis L. Lowenheim, and Richard W. Van Wagenen. 1957. Political Community and the North Atlantic Area: International Organization in the Light of Historical Experience. Princeton, N.J.: Princeton University Press.

Dirlik, Arif. 1993. The Asia-Pacific in Asian-American Perspective. In What Is in a Rim? Critical Perspectives on the Pacific Region Idea, edited by Arif Dirlik, 305-29. Boulder, Colo.: Westview Press. 
Dower, John. 1986. War Without Mercy: Race and Power in the Pacific War. New York: Pantheon Books.

Duffield, John S. 1998. World Power Forsaken: Political Culture, International Institutions, and German Security Policy After Unification. Stanford, Calif.: Stanford University Press.

- 2001. Why is There No APTO? Why is There No OSCAP? Asia-Pacific Security Institutions in Comparative Perspective. Contemporary Security Policy 22 (2):69-95.

Dulles, John Foster. 1952. Security in the Pacific. Foreign Affairs 30 (2):175-87.

1954. The Issues at Geneva: Address by Secretary Dulles. The Department of State Bulletin 30 (777):739-44.

Eisenhower, Dwight D. 1963. The White House Years: Mandate For Change: 1953-1965. New York: Doubleday and Company.

Emmerson, Donald K. 1994. Organizing the Rim: Asia Pacific Regionalism. Current History 93 (587):435-39.

Fearon, James, and Alexander Wendt. 2001. Rationalism Versus Constructivism: A Skeptical View. Unpublished manuscript, Stanford University and University of Chicago.

Finnemore, Martha. 1996. Constructing Norms of Humanitarian Intervention. In The Culture of National Security: Norms and Identity in World Politics, edited by Peter J. Katzenstein, 153-85. New York: Columbia University Press.

Folly, Martin H. 1988. Breaking the Vicious Circle: Britain, The United States, and the Genesis of the North Atlantic Treaty. Diplomatic History 12 (1):59-77.

Fordham, Benjamin O. 1998. Economic Interests, Party, and Ideology in Early Cold War Era U.S. Foreign Policy. International Organization 52 (2):359-96.

Gheciu, Alexandra. 2001. NATO's History: The Politics of "Securing the West" Since 1949. Ph.D. diss. draft, Cornell University, Ithaca, N.Y.

Gienow-Hecht, Jessica C. E. 2000. Shame on US? Academics, Cultural Transfer, and the Cold War-A Critical Review. Diplomatic History 24 (3):465-94.

Grieco, Joseph M. 1993. Understanding the Problem of Cooperation: The Limits of Neoliberal Institutionalism and the Future of Realist Theory. In Neorealism and Neoliberalism: The Contemporary Debate, edited by David A. Baldwin, 310-38. New York: Columbia University Press.

Haftendorn, Helga, Robert O. Keohane, and Celeste A. Wallander, eds. 1999. Imperfect Unions: Security Institutions over Time and Space. Oxford: Oxford University Press.

Hampton, Mary. 1995. NATO at the Creation: U.S. Foreign Policy, West Germany, and the Wilsonian Impulse. Security Studies 4 (3):610-56.

. 1998/99. NATO, Germany, and the United States: Creating Positive Identity in Trans-Atlantia. Security Studies 8 (2-3):235-69.

Henrikson, Alan K. 1975. The Map as an Idea: The Role of Cartographic Imagery During the Second World War. The American Cartographer 2 (1):19-53.

1980. The Creation of the North Atlantic Alliance, 1948-1952. Naval War College Review 33 (3):4-39.

Hess, Gary R. 1990. The American Search for Stability in Southeast Asia: The SEATO Structure of Containment. In The Great Powers in East Asia 1953-1960, edited by Warren I. Cohen and Akira Iriye, 272-95. New York: Columbia University Press.

Horne, Gerald. 1999. Race from Power: U.S. Foreign Policy and the General Crisis of "White Supremacy." Diplomatic History 23 (3):437-61.

Hunt, Michael. 1987. Ideology and U.S. Foreign Policy. New Haven, Conn.: Yale University Press.

Ikenberry, G. John. 2001. Afier Victory: Institutions, Strategic Restraint, and the Rebuilding of Order after Major Wars. Princeton, N.J.: Princeton University Press.

Isaacson, Walter, and Evan Thomas. 1986. The Wise Men: Six Friends and the World They Made. New York: Touchstone.

Jackson, Henry M., ed. 1967. The Atlantic Alliance: Jackson Subcommittee Hearings and Findings. New York: Praeger. 
Jackson, Patrick Thaddeus. 2001. Occidentalism: Rhetoric, Process, and Postwar German Reconstruction. Ph.D. diss., Columbia University, New York.

Jervis, Robert. 1997. System Effects: Complexity in Political and Social Life. Princeton, N.J.: Princeton University Press.

Johnston, Alastair Iain. 1995. Cultural Realism: Strategic Culture and Grand Strategy in Chinese History. Princeton, N.J.: Princeton University Press.

Kaplan, Lawrence S. 1984. The United States and NATO: The Formative Years. Lexington: University Press of Kentucky.

Katzenstein, Peter J. 1996a. Introduction: Alternative Perspectives on National Security. In The Culture of National Security: Norms and Identity in World Politics, edited by Peter J. Katzenstein, 1-32. New York: Columbia University Press.

Katzenstein, Peter J., ed. 1996b. The Culture of National Security: Norms and Identity in World Politics. New York: Columbia University Press.

Kennan, George F. 1967. Memoirs, 1925-1950. Boston: Little, Brown and Company.

Kim, B. Sang Joon. 1965. The United States and SEATO. Ph.D. diss., Yale University, New Haven, Conn.

Kimball, Warren F. 1984. Churchill and Roosevelt: The Complete Correspondence. 3 vols. Princeton, N.J.: Princeton University Press.

Kohno, Masaru. 1996. Limits of Neoliberal Institutionalism: Learning from the Failure of Multilateral Institutions in East Asian Security. Paper presented at the conference organized jointly by the Japan Association of International Studies and the International Studies Association, Makuhari, Japan.

Koremenos, Barbara, Charles Lipson, and Duncan Snidal. 2001. Rational Design: Looking Back to Move Forward. International Organization 55 (4): 1051-1082.

Kurth, James. 2001. The Next NATO: Building an American Commonwealth of Nations. The National Interest 65:5-16.

Laffey, Mark, and Jutta Weldes. 1997. Beyond Belief: Ideas and Symbolic Technologies in the Study of International Relations. European Journal of International Relations 3 (2):193-237.

Lake, David A. 1999. Entangling Relations: American Foreign Policy in Its Century. Princeton, N.J.: Princeton University Press.

Lauren, Paul Gordon. 1988. Power and Prejudice: The Politics of Diplomacy and Racial Discrimination. Boulder, Colo.: Westview Press.

Legro, Jeffrey W. 2000. Whence American Internationalism. International Organization 54 (2):253-90.

Lewis, Martin W., and Kären Wigen. 1997. The Myth of Continents: A Critique of Metageography. Berkeley: University of California Press.

Lundestad, Geir. 1980. America, Scandinavia, and the Cold War, 1945-1949. New York: Columbia University Press.

1999. "Empire by Invitation" in the American Century. Diplomatic History 23 (2):189-217.

Maier, Charles S. 1978. The Politics of Productivity: Foundations of American International Economic Policy After World War II. In Between Power and Plenty: Foreign Economic Policies of Advanced Industrial States, edited by Peter J. Katzenstein, 23-49. Madison: University of Wisconsin Press.

Makhijani, Arjun. 1995. "Always" the Target? Bulletin of the Atomic Scientists 51 (3):23-27.

Marks, Frederick W., III. 1993. Power and Peace: The Diplomacy of John Foster Dulles. Westport, Conn.: Praeger.

McMahon, Robert J. 1999. The Limits of Empire: The United States and Southeast Asia Since World War II. New York: Columbia University Press.

Mercer, Jonathan. 1995. Anarchy and Identity. International Organization 49 (2):229-52.

Modelski, George. 1962. SEATO: Its Functions and Organization. In SEATO: Six Studies, edited by George Modelski, 1-45. Melbourne: F. W. Chesire.

Murphy, Robert D. 1954. Japan's Progress and Prospects: Address Made Before the Japan Society at New York. Department of State Bulletin 30 (771):513-17.

Nau, Henry. 2002. Identity and Power in American Foreign Policy. Ithaca, N.Y.: Cornell University Press. 
Neumann, Iver B. 1999. Uses of the Other: 'The East' in European Identity Formation. Minneapolis: University of Minnesota Press.

Nolt, James H. 1999. Liberalizing Asia. World Policy Journal. 16 (2):94-1 18.

Oba, Mie, and Susumu Yamakage. 1998. In Search for Regional Identity: A Tale of Two Liminal Nations in Asia and the Pacific. Unpublished manuscript, University of Tokyo, Komaba campus.

Paasi, Anssi. 1986. The Institutionalization of Regions: A Theoretical Framework for Understanding the Emergence of Regions and the Constitution of Regional Identity. Fennia 164 (1):105-46.

Polelle, Mark. 1999. Raising Cartographic Consciousness: The Social and Foreign Policy Vision of Geopolitics in the Twentieth Century. Lanham, Md.: Lexington Books.

Prentice, Deborah A., and Dale T. Miller, eds. 1999. Cultural Divides: Understanding and Overcoming Group Confict. New York: Russell Sage Foundation.

Purifoy, Lewis McCarroll. 1976. Harry Truman's China Policy: McCarthyism and the Diplomacy of Hysteria 1947-1951. New York: Franklin Watts.

Reid, Escott. 1977. Time of Fear and Hope: The Making of the North Atlantic Treaty, 1947-1949. Ontario: McClelland and Stewart.

Reiter, Dan. 1996. Crucible of Beliefs: Learning, Alliances, and World Wars. Ithaca, N.Y.: Cornell University Press.

Rotter, Andrew J. 1987. The Path to Vietnam: Origins of the American Commitment to Southeast Asia. Ithaca, N.Y.: Cornell University Press.

Ruggie, John Gerard. 1993. Multilateralism: The Anatomy of an Institution. In Multilateralism Matters: The Theory and Praxis of an Institutional Form, edited by John Gerard Ruggie, 3-47. New York: Columbia University Press.

1994. Third Try at World Order? America and Multilateralism After the Cold War. Political Science Quarterly 109 (4):553-70.

. 1997. The Past as Prologue: Interests, Identity, and American Foreign Policy. International Security 21 (4):89-125.

1998. Constructing the World Polity: Essays on International Institutionalization. London: Routledge.

Rusk, Dean, and Khomen Thanat. 1962. Joint Statement, Washington, 6 March 1962. The Department of State Bulletin 46 (1187):498-99.

Sar Desai, D.R. 1997. Southeast Asia: Past and Present, 4th ed. Boulder, Colo.: Westview Press.

Schimmelfennig, Frank. 2001. The Community Trap: Liberal Norms, Rhetorical Action, and the Eastern Enlargement of the European Union. International Organization 55 (1):47-80.

Simon, Sheldon W. 1993. The Clinton Administration and Asian Security: Toward Multilateralism. Australian Journal of International Affairs 47 (2):250-62.

Skrentny, John D. n.d. The Minority Rights Revolution. Unpublished manuscript, University of California, San Diego.

Smith, Tony. 2000. Foreign Attachments: The Power of Ethnic Groups in the Making of American Foreign Policy. Cambridge, Mass.: Harvard University Press.

Spiro, David E. 1999. The Hidden Hand of American Hegemony: Petrodollar Recycling and International Markets. Ithaca, N.Y.: Cornell University Press.

Tajfel, Henri, ed. 1978. Differentiation Between Social Groups: Studies in the Social Psychology of Intergroup Relations. London: Academic Press.

Tajfel, Henri, and John C. Turner. 1986. The Social Identity Theory of Intergroup Behavior. In Psychology of Intergroup Relations, 2d ed., edited by Stephen Worchel and William G. Austin, 7-24. Chicago: Nelson Hall.

Trachtenberg, Marc. 1999. A Constructed Peace: The Making of the European Settlement, 1945-1963. Princeton, N.J.: Princeton University Press.

Truman, Harry S. 1956. Memoirs. Vol. 2, Years of Trial and Hope. Garden City, N.J.: Doubleday and Company.

Ullman, Richard. 1999. The U.S. and the World: An Interview with George Kennan. New York Review of Books 46 (13):4-6. 
U.S. Department of State. 1984. Foreign Relations of The United States: 1952-1954. Vol. 12, East Asia and the Pacific, Part I. Washington, D.C.: U.S. Government Printing Office.

U.S. Senate. 1949. North Atlantic Treaty: Hearings Before the Committee on Foreign Relations, 81 st Cong., 1st sess. Washington, D.C.: U.S. Government Printing Office.

1954. The Southeast Asia Collective Defense Treaty: Hearing Before the Committee on Foreign Relations, 83d Cong., 2d sess. Washington, D.C.: U.S. Government Printing Office.

1973. The Vandenberg Resolution and the North Atlantic Treaty: Hearings Held in Executive Session Before the Committee on Foreign Relations, 80th Cong., 2d sess. Washington D.C.: U.S. Government Printing Office.

Urwin, Derek W. 1995. The Community of Europe: A History of European Integration Since 1945. New York: Longman.

Wallander, Celeste A. 1999. Mortal Friends, Best Enemies: German-Russian Cooperation After the Cold War. Ithaca, N.Y.: Cornell University Press.

2000. Institutional Assets and Adaptability: NATO After the Cold War. International Organization 54 (4):705-35.

Walt, Stephen M. 1987. The Origins of Alliances. Ithaca, N.Y.: Cornell University Press.

Warshaw, Steven. 1975. Southeast Asia Emerges: A Concise History of Southeast Asia from Its Origins to the Present. Berkeley, Calif.: The Diablo Press.

Watanabe, Paul Y. 2001. Global Forces, Foreign Policy, and Asian Pacific Americans. Political Science and Politics 34 (3):639-44.

Webb, Leicester C. 1962. Australia and SEATO. In SEATO: Six Studies, edited by George Modelski, 49-82. Melbourne: F. W. Chesire.

Weber, Steve. 1991. Multilateralism in NATO: Shaping the Postwar Balance of Power, 1945-1961. Berkeley: University of California Press.

1993. Shaping the Postwar Balance of Power: Multilateralism in NATO. In Multilateralism Matters: The Theory and Praxis of an Institutional Form, edited by John Gerard Ruggie, 233-92. New York: Columbia University Press.

Wendt, Alexander. 1999. Social Theory of International Politics. Cambridge: Cambridge University Press.

Westerfield, H. Bradford. 1955. Foreign Policy and Party Politics: Pearl Harbor to Korea. New Haven, Conn.: Yale University Press.

Williams, Lee E. 1976. Southeast Asia: A Short History. New York: Oxford University Press. 